\title{
Клінічні випадки фотосенсибілізації, асоційованої із SARS-CoV-2- інфекцією і їі лікуванням
}

\author{
Я.Ф. Кутасевич, І.О. Олійник, І.О. Маштакова, М.О. Вітковська \\ ДУ «Інститут дерматології та венерології НАМН України»
}

\begin{abstract}
Резюме
Мета. Підвищити обізнаність лікарів щодо запобігання розвитку фотосенсибілізації в пацієнтів, що перенесли COVID-19.

Матеріали і методи. Проведено огляд літератури, а також аналіз клінічних випадків фотосенсибілізації, асоційованої із SARSCoV-2-інфекцією та її лікуванням.
\end{abstract}

Результати. У статті на підставі даних літератури і клінічного досвіду наведено можливі причини проявів і загострень фотоалергічного контактного дерматиту, подано клінічні випадки фотосенсибілізації, асоційованої із коронавірусною інфекцією.

Висновки. Актуальним у літній час стає питання захисту від ультрафіолетового випромінювання, особливо у час пандемії, пов'язаної з появою нової коронавірусної інфекції.

Ключові слова: фотосенсибілізація, COVID-19, дерматит, лікарські засоби, клінічні випадки.

DOI: 10.33743/2308-1066-2021-2-12-14

\section{Вступ}

У зв’язку з появою нової коронавірусної інфекції та зміною епідемічної обстановки актуальним у літній час постає питання захисту від ультрафіолетового випромінювання. У групі ризику знаходяться пацієнти, які хворіли на коронавірусну інфекцію, а також пацієнти, що мають раніше діагностовані хронічні дерматози і перенесли SARS-CoV-2-інфекцію.

Захист шкіри від сонця забезпечується меланогенезом, який безпосередньо залежить від дії ультрафіолетового випромінювання. Ізоляція в зимово-весняний період характеризується низькими рівнем і інтенсивністю вироблення меланіну за будь-якого фототипу шкіри. Уповільнення процесів меланогенезу призводить до поступового погіршення світлової акліматизації шкіри, що робить їі чутливішою до дії агресивних сонячних променів і виникнення фотосенсибілізації [5]. Цей процес є проявом підвищеної чутливості організму до дії ультрафіолетового випромінювання, що розвивається як за негайним, так і за уповільненим типом.

Причиною фотосенсибілізації та розвитку фотодерматозів на ділянках шкіри, які зазнали впливу сонячних променів, можуть бути хімічні речовини. При фотоалергічній реакції хімічна речовина або лікарський засіб, який міститься в шкірі, поглинає фотони і утворює нову сполуку, що зв'язується з мембранними і цитоплазматичними білками, утворюючи антиген. Фотоалергічні реакції розвиваються лише в людей, які мають особливості або зміни імунітету [3].
Спричиняти фотосенсибілізацію, фотоалергічні і фототоксичні реакції здатні такі лікарські засоби:

- нестероїдні протизапальні препарати (піроксикам, ібупрофен, кетопрофен, індометацин, диклофенак);

- інгібітори АПФ (каптоприл, еналаприл, лізиноприл, периндоприл, раміприл);

- антибіотики і протимікробні засоби (триметоприм, сульфаніламіди, тетрациклін, доксициклін, міноциклін, окситетрациклін, фторхінолони, гризеофульвін, амоксицилін);

- $\mathrm{H}_{1}$ - і $\mathrm{H}_{2}$-блокатори (прометазин, ранітидин, дифенгідрамін, циметидин);

- препарати, які застосовують для лікування захворювань серцево-судинної системи (дигітоксин, аміодарон, фуросемід, міноксидил, метилдофа, ніфедипін);

- нейролептики, седативні засоби та антидепресанти (доксепін, амітриптилін, флуоксетин);

- протидіабетичні засоби (хлорпропамід, глібенкламід);

- системні глюкокортикостероїди - рідко (гідрокортизон, преднізолон, метилпреднізолон) [4].

Як можна бачити, багато з цього списку препаратів можуть застосовуватись для лікування коронавірусної хвороби або в разі виникнення ускладнень.

Останніми роками встановлено, що в основі розвитку фотоалергічного контактного дерматиту (ФАКД) лежить гіперчутливість шкірних покривів, опосередкована Т-лімфоцитами у відповідь на дію фотоалергену в пацієнта, який раніше був сенсибілізований причинно-значимою хімічною речовиною або антигеном, здатним провокувати перехресні алергічні реакції [1]. 
Мета роботи - підвищити обізнаність лікарів щодо запобігання розвитку фотосенсибілізації в пацієнтів, що перенесли COVID-19.

\section{Матеріали і методи дослідження}

Проведено огляд літератури й аналіз клінічних випадків фотосенсибілізації, асоційованої із SARS-CoV-2інфекцією та їі лікуванням.

\section{Результати та обговорення}

До клініки ДУ «Інститут дерматології та венерології НАМН України» звернувся по медичну допомогу пацієнт зі скаргами на свербіж, сухість, лущення шкіри, появу дрібних тріщин та дискомфорт.

3 анамнезу відомо: чоловік, 57 років, хворіє менше 2 тиж, коли вперше почав відмічати лущення шкіри на кінчиках пальців обох верхніх кінцівок. Контакту 3 хімічними речовинами не мав. Зв'язує появу стійкої гіперемії та лущення шкіри з підвищеною інсоляцією. Самостійно не лікувався. Хворів на COVID-19 у травні 2021 р. в середньотяжкій формі. Алергоанамнез і спадковість не обтяжені. Такий стан спостерігається вперше, зі слів пацієнта, інсоляцію до COVID-19 хвороби переносив без особливостей.

Об'єктивно: дерматоз локалізований на верхніх кінцівках, шиї. Має гострозапальний перебіг. Шкіра в осередках дерматозу гіперемована, запальна. Лущення дрібнолусочкове, помірне. На кінчиках пальців відзначаються неглибокі множинні тріщини з утворенням геморагічних кірок. Папульозний висип не схильний до злиття. Дермографізм - червоний (рис. 1).

На підставі скарг хворого, даних анамнезу та клінічної картини встановлено діагноз: ФАКД.

Другий пацієнт також звернувся по медичну допомогу до ДУ «Інститут дерматології та венерології НАМН України» зі скаргами на почервоніння шкіри верхніх кінцівок, шиї, волосистої частини голови, лущення шкіри, свербіж, тріщини, дискомфорт.

3 анамнезу: чоловік, 45 років, хворіє більше 6 міс, коли вперше почав відмічати сухість шкіри кистей і появу лущення. Стабільно працює з хімічними речовинами. Самостійно лікувався емолієнтами з досягненням ефективного результату, по спеціалізовану медичну допомогу раніше не звертався. Відмічає різке погіршення стану шкіри після інсоляції.

Приймав нестероїдні протизапальні засоби (аспірин, ібупрофен) до SARS-CoV-2-інфекції без побічних реакцій. Перехворів на COVID-19 у жовтні 2020 р. у середньотяжкій формі. Під час лікування також приймав нестероїдні протизапальні препарати довгостроково для купірування больового синдрому, після чого почав відмічати поступове погіршення стану шкіри.

Алергоанамнез і спадковість не обтяжені. Зі слів пацієнта, цей стан спостерігається вперше, інсоляцію до COVID-19 переносив без особливостей.

Об'єктивно: Дерматоз локалізований на верхніх кінцівках, волосистій частині голови, шиї, гомілках. Має гострозапальний перебіг. Відмічається поява стійкої гіперемії відкритих ділянок шкіри, запалення та подразнення шкіри. Мають місце глибокі тріщини, лущення шкіри кистей і передпліч, поява дрібного папульозного висипу, не схильного до злиття. Шкіра щільна. Дермографізм - червоний (рис. 2).

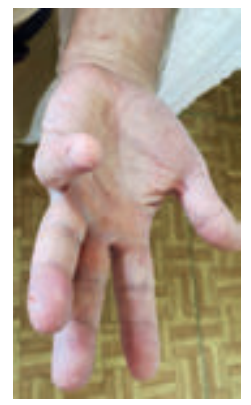

a

Рис. 1. Пацієнт Р., 57 років, діагноз: ФАКД. До лікування
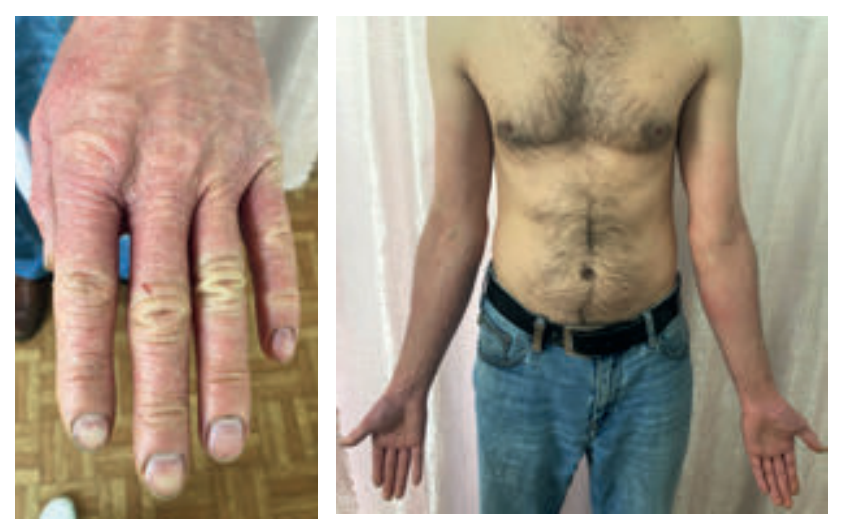

a

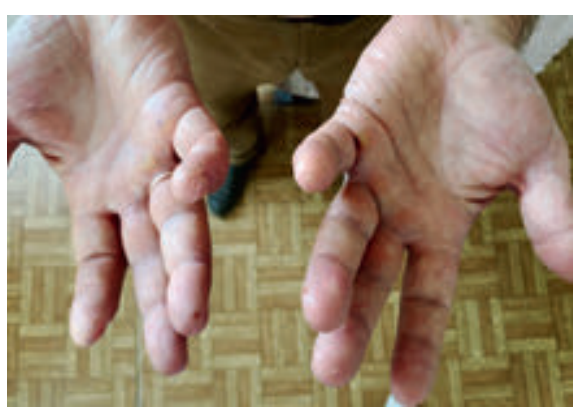

6

б
Рис. 2. Пацієнт М., 45 років, діагноз: ФАКД. До лікування

На підставі скарг хворого, даних анамнезу та клінічної картини встановлено діагноз: ФАКД.

Описані випадки є проявом фотодерматозів у пацієнтів, які перенесли SARS-CoV-2-інфекцію. Можливими причинами погіршення стану цих пацієнтів можуть бути імунологічні порушення, пов'язані з COVID-19, а також препарати, що застосовувалися під час лікування інфекції.

Фотоалергічні реакції виникають лише в сенсибілізованих осіб і опосередковані імунними механізмами [2]. Висипання представлені папулами, везикулами, мокнуттям, ліхенізацією.

Вираженість шкірних реакцій залежить від хімічної природи подразника, концентрації, тривалості експозиції, інтенсивності і довжини світлових хвиль, тривалості опромінення, здатності шкіри до поглинання світла (визначається товщиною рогового шару, кількістю меланіну, секрецією шкірних залоз).

\section{Висновки}

Ще декілька десятиліть тому ФАКД вважався великою рідкістю, але сьогодні його поширеність значно зросла у зв’язку зі зміною характеру життя, застосуванням карантинних заходів і різким обмеженням інсоляції населення. Важливим постає питання захисту шкіри, особливо у весняно-літній період.

Щоб уникнути світлочутливих реакцій, важливо знати про фотосенсибілізувальні властивості таких препаратів і інформувати про це пацієнтів під час консультацій.

Рекомендовано застосування косметики, що містить УФ-фільтри, і навпаки, скорочення застосування декоративної косметики та парфумерних продуктів, оскільки вони можуть містити фотосенсибілізатори, які підвищують чутливість шкіри до сонячного світла. 


\section{Література}

1. Зайков С.В. Фотосенсибілізація і фотоалергія. Пульмонологія, Алергологія Риноларингологія. 2015. № 2 (30). С. 46-47.

2. Drug-Induced Photosensitivity - a Continuing Diagnostic Challenge / L. Lugović-Mihić, T. Duvančić, I. Ferček et al. Acta Clin. Croat. 2017. Vol. 56, Iss. 2. P. 277-283.

3. Middleton D.W., Hunter H.L. Short back and sides: photodermatosis presentation related to hairstyling during the COVID-19 pandemic. Clin. Exp. Dermatol. 2021. May 28. doi: 10.1111/ ced. 14767.

ulti-omics-based identification of SARS-CoV-2 infection biology and candidate drugs against COVID-19 / D. Barh, S. Tiwari, M.E. Weener et al. Comput. Biol. Med. 2020. Vol. 126. Article ID: 104051

5. Photosensitive disorders of the skin with ocular involvement / P.V. Rambhatla, J. Brescoll, F. Hwang et al. Clin. Dermatol. 2015. Vol. 33, Iss. 2. P. 238-246.

\section{References}

1. Zaikov SV. Fotosensybilizatsiia i fotoalerhiia [Photosensitization and photoallergy]. Pulmonolohiia, Alerholohiia, Rynolarynholohiia. 2015;2(30):46-47 [in Rus.]

2. Lugović-Mihić L, Duvančić T, Ferček I, Vuković $P$, Japund ić I, esić D. Drug-Induced Photosensitivity - a Continuing Diagnostic Challenge. Acta Clin Croat. 2017;56(2):277-283.

3. Middleton DW, Hunter HL. Short back and sides: photodermatosis presentation related to

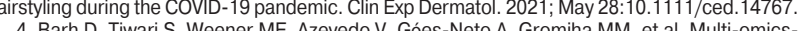
4. Bah D, Twari S, Weener ME, Azevedo V, Goes-Neto A, Gromiha MM, et al. Multi-omicsbased identification of SARS-CoV-2 in.ection biology and candidate drugs against COVID-19.

5. Rambhatla PV, Brescoll J, Hwang F, Juzych M, Lim HW. Photosensitive disorders of the skin with ocular involvement. Clin Dermatol. 2015;33(2):238-246.

\section{КЛИНИЧЕСКИЕ СЛУЧАИ СЕНСИБИЛИЗАЦИИ, АССОЦИИРОВАННОЙ C SARS-COV-2-ИНФЕКЦИЕЙ И ЕЕ ЛЕЧЕНИЕМ}

Я.Ф. Кутасевич, И.А. Олейник, И.А. Маштакова, М.А. Витковская

ГУ «Институт дерматологии и венерологии НАМН Украины»

\section{Резюме}

Цель. Повысить осведомленность врачей по предупреждению развития фотосенсибилизации у пациентов, перенесших COVID-19.

Материалы и методы. Проведен обзор литературы и анализ клинических случаев фотосенсибилизации, ассоциированной c SARS-CoV-2-инфекцией и ее лечением.

Результаты. В статье на основании данных литературы и клинического опыта приведены возможные причины проявлений и обострений фотоаллергического контактного дерматита, представлены клинические случаи фотосенсибилизации, ассоциированной с коронавирусной инфекцией.

Выводы. Актуальным в летнее время становится вопрос защиты от ультрафиолетового излучения, особенно в период пандемии, связанной с появлением новой коронавирусной инфекции.

Ключевые слова: фотосенсибилизация, COVID-19, дерматит, лекарственные средства, клинические случаи.

\section{CLINICAL CASES OF SENSITIZATION ASSOCIATED WITH SARS-COV-2-INFECTION AND ITS TREATMENT}

Ya.F. Kutasevych, I.O. Oliinyk, I.O. Mashtakova, M.O. Vitkovska

SE «Institute of Dermatology and Venereology of NAMS of Ukraine»

\section{Abstract}

The objective. Raise physician awareness to prevent the development of photosensitization in patients with COVID-19.

Materials and methods. A review of the literature and analysis of clinical cases of photosensitization associated with SARS-CoV-2infection and its treatment carried out.

Results. Based on the literature and clinical experience, the article presents the possible causes of manifestations and exacerbations of photoallergic contact dermatitis, presents clinical cases of photosensitization associated with coronavirus infection.

Conclusions. The issue of protection against ultraviolet radiation is relevant in the summer, especially during a pandemic associated with the emergence of a new coronavirus infection.

Key words: photosensitization, COVID-19, dermatitis, drugs, clinical cases.

Відомості про авторів:

Кутасевич Яніна Францівна - д-р мед. наук, професор, директор ДУ «/нститут дерматології та венерології НАМН України». E-mail: otdderm@ukr.net

ORCID ID: https://orcid.org/0000-0001-8706-1487

Олійник Ірина Олександрівна - д-р мед. наук, ст. наук. співроб., головний наук. співроб. відділу дерматології, інфекційних та паразитарних захворювань шкіри Ду «Інститут дерматології та венерології НАMН України». E-mail: otdderm@ukr.net ORCID ID: https://orcid.org/0000-0002-6408-830X

Маштакова Ірина Олексіївна - канд. мед. наук, ст. наук. співроб., ст. наук. співроб. відділу дерматології, інфекційних та паразитарних захворювань шкіри ДУ «Інститут дерматології та венерології НАМН України». E-mail: mashtakova_derm@ukr.net ORCID ID: https://orcid.org/0000-0002-3592-6896

Вітковська Марія Олександрівна - аспірант ду «Інститут дерматології та венерології НАМН України». E-mail: тагіlnoy@gmail. com

ORCID ID: https://orcid.org/0000-0002-6453-5886 